\title{
KEANEKARAGAMAN JENIS BURUNG DI HUTAN PINUS DAN HUTAN CAMPURAN MUARASIPONGI KABUPATEN MANDAILING NATAL SUMATERA UTARA
}

\section{(DIVERSITY OF BIRD SPECIES ON PINE AND MIXED FOREST MUARASIPONGI MANDAILING NATAL REGENCY NORTH SUMATRA)}

\author{
Muhammad Rohiyan, Agus Setiawan, dan Elly Lestari Rustiati \\ Jurusan Kehutanan, Fakultas Pertanian, Universitas Lampung \\ Jln. Prof. Dr. Soemantri Brojonegoro No.1 Gedung Meneng, Bandar Lampung \\ Email: muhammadrohiyan@gmail.com
}

\begin{abstract}
ABSTRAK
Muarasipongi mempunyai hutan pinus dan hutan campuran yang memberikan kontribusi besar terhadap keberadaan dan keanekaragaman hayati baik tumbuh-tumbuhan, maupun satwa liar. Penelitian keanekaragaman jenis burung di hutan pinus dan hutan campuran Muarasipongi, merupakan wujud kepedulian terhadap konservasi jenis burung. Penelitian ini dilakukan dengan metode titik hitung pada hutan campuran dan hutan pinus. Data dianalisis kemudian digunakan untuk menghitung indeks keanekaragaman jenis, kesamarataan, dan kesamaan komunitas. Pengamatan dilakukan selama enam kali pengulangan. Penelitian yang telah dilakukan selama bulan Agustus 2013, diketahui di hutan pinus terdapat 19 jenis burung dan di hutan campuran terdapat 24 jenis serta 5 jenis burung yang ditemukan kedua tipe hutan. Secara keseluruhan, burung yang ditemukan di hutan pinus dan hutan campuran Muarasipongi berjumlah 38 jenis burung yang berasal dari 20 famili. Nilai indeks keanekaragaman (H') jenis burung di hutan pinus dan hutan campuran tersebut adalah sebesar 3.358, hal ini menunjukkan bahwa indeks keanekaragaman $\left(\mathrm{H}^{\prime}\right)$ jenis burung di hutan pinus dan hutan campuran Muarasipongi tinggi dengan kriteria bahwa $\left(\mathrm{H}^{\prime}>3\right)$. Nilai kesamarataan di hutan pinus dan campuran Muarasipongi bernilai 0.923, maka komunitas dimasukkan ke dalam kategori stabil serta memiliki indeks kesamaan (IS) atau Similarity index yang bernilai 0.277 yang berarti bahwa kesamaan spesies antar kedua habitat memang berbeda.
\end{abstract}

Kata kunci : burung, indeks, keanekaragaman, pelestarian, perlindungan

\section{ABSTRACT}

Muarasipongi pine and mixed forests contribute greatly to the biodiversity wildlife. The study of bird species diversity in pine and mixed forests Muarasipongi, to support the preservation and protection efforts on biodiversity especially bird species. This research was conducted on August 2013 by the point count method on Muarasipongi pine and mixed forest then mark and record all the birds over a predetermined period of time before moving to the next point. The data obtained were analyzed and then used to calculate the index of species diversity equality, and community similarity were determined. Observations were made during six repetitions. There are 19 species pine forest, 24 species in the mixed forest and 5 types of birds found in both forest. Total birds found in Muarasipongi 38 species of 20 families. Diversity index $\left(H^{\prime}\right)$ (3.358). The equality index is 0.923, and has a (IS) or Similarity index is worth 0.277 which means that the similarity between the two species is different habitats.

Keywords : birds, diversity, index, preservation, protection 


\section{PENDAHULUAN}

Burung merupakan satwa liar yang memiliki kemampuan hidup hampir semua tipe habitat, dan mempunyai mobilitas yang tinggi dengan kemampuan adaptasi terhadap berbagai tipe habitat yang luas (Welty, 1982).

Merupakan kelompok hewan bertulang belakang (vertebrata) yang memiliki bulu dan sayap. Diperkirakan terdapat sekitar 8800-10200 spesies burung di seluruh dunia dan sekitar 1500 jenis di antaranya ditemukan di Indonesia serta 465 jenis terdapat di Pulau Sumatera (Primark, Supriatna, Indrawan, Kramadibrata, 1998).

Muarasipongi adalah kecamatan yang terletak di Kabupaten Mandailing Natal, Provinsi Sumatera Utara dan berbatasan langsung dengan Provinsi Sumatera Barat. Menurut (Harahap, 2004) Muarasipongi termasuk salah satu kecamatan dari 13 kecamatan yang ada Mandailing Natal yang masuk dalam DAS dan SUB DAS Batang Gadis, mempunyai hutan campuran dan hutan pinus yang memberikan kontribusi besar terhadap keberadaan dan keanekaragaman hayati baik tumbuh-tumbuhan, maupun satwa liar. Namun, hutan pinus dan hutan campuran Muarasipongi berpotensi mengalami kerusakan akibat penebangan ilegal serta konversi lahan dan dapat merusak habitat serta keanekaragaman jenis burung.

Kerusakan hutan di Muarasipongi juga disebabkan oleh aktivitas penambangan tradisional yang dilakukan oleh masyarakat. Penelitian keanekaragaman jenis burung di hutan pinus dan hutan campuran Muarasipongi, merupakan wujud kepedulian terhadap pelestarian dan upaya perlindungan terhadap keanekaragaman hayati terutama keanekaragaman jenis burung.

\section{METODE PENELITIAN}

\section{Waktu dan Tempat Penelitian}

Penelitian ini dilakukan pada bulan Agustus 2013 di hutan pinus dan hutan campuran Muarasipongi, Kabupaten Mandailing Natal, Provinsi Sumatera Utara (Gambar 1).

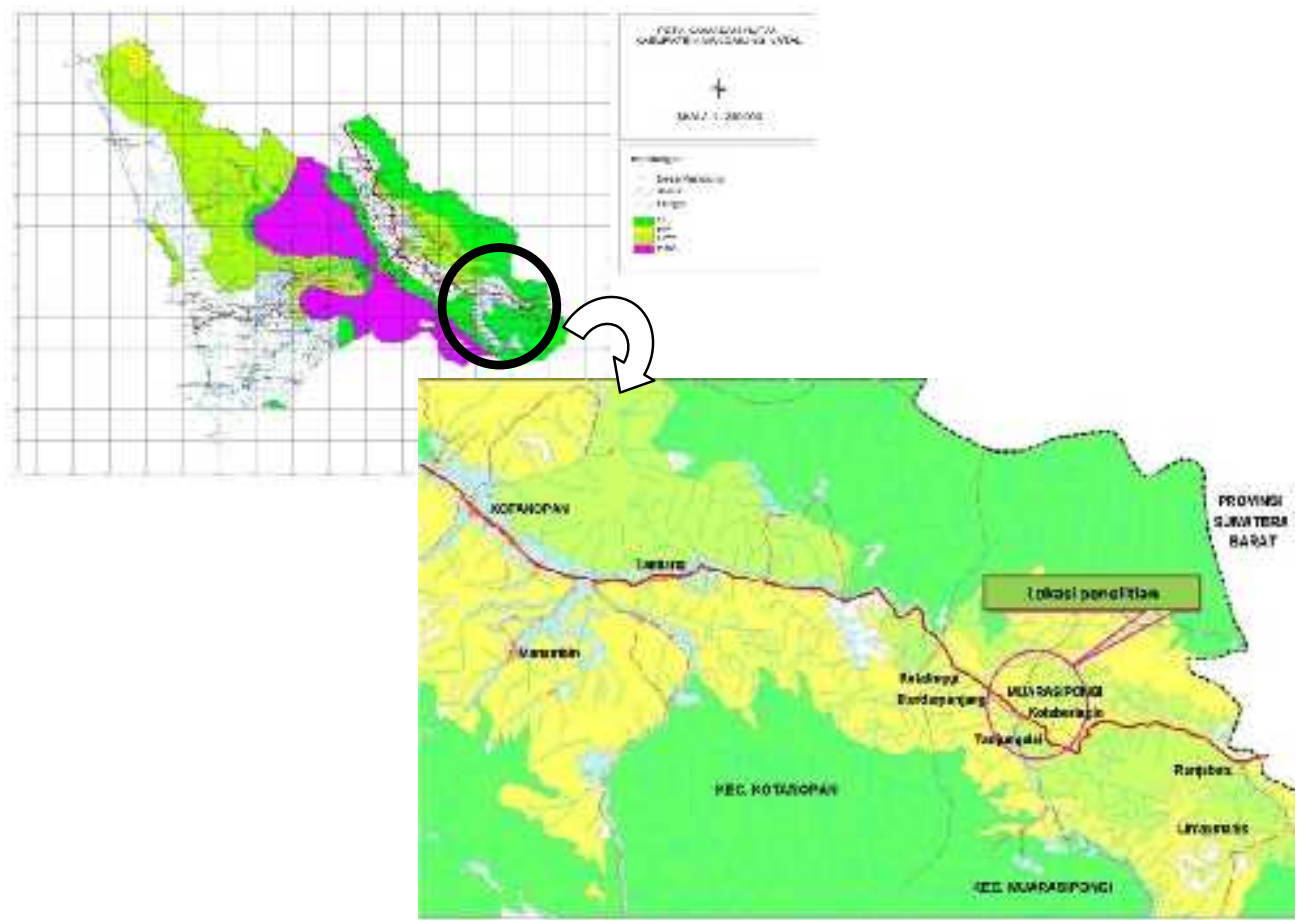

Gambar 1. Peta lokasi penelitian yaitu Kecamatan Muarasipongi, Kabupaten Mandailing Natal, Provinsi Sumatera Utara. 


\section{Objek dan Alat}

Objek yang diamati dalam penelitian ini adalah jenis-jenis burung yang ada di hutan pinus dan hutan campuran Muarasipongi Kabupaten Mandailing Natal Provinsi Sumatera Utara. Alat yang digunakan dalam penelitian ini meliputi teropong binokuler, jam tangan, serta buku Panduan Pengamatan Burung-Burung di Sumatera, Jawa, Bali, dan Kalimantan (MacKinnon, J., Philips, K., Balen, 2010).

\section{Batasan Penelitian}

Batasan penelitian meliputi:

1. Waktu penelitian dilakukan selama 12 hari merupakan waktu efektif selama pengamatan.

2. Penelitian dilaksanakan sesuai dengan kondisi cuaca yaitu cuaca cerah dan mendung, apabila hujan maka penelitian tidak dilaksanakan dan diganti dengan hari lain.

3. Sampel yang digunakan adalah burung yang ditemui di kawasan atau lokasi pengamatan.

\section{Metode Pengumpulan Data}

1. Pengumpulan data primer

a. Metode survei pendahuluan

Metode survei pendahuluan dilakukan dengan tujuan untuk menentukan lokasi penelitian yang representatif berdasarkan karakteristik habitat dengan frekuensi perjumpaan berbagai jenis burung.

b. Metode point count (titik hitung)

Data mengenai keanekaragaman jenis burung dapat diperoleh dengan menggunakan metode point count (titik hitung) (Bibby, 2000). Teknis pengambilan data secara point count (titik hitung) dilakukan dengan :

- Pengamatan dilakukan pada dua tipe habitat yaitu hutan pinus dan hutan campuran. Data yang dicatat adalah jenis burung yang ditemukan serta berapa jumlah individu burung tersebut.

- Pengamatan dilakukan pada pagi hari mulai jam 06.00 - 08.30 WIB dan pada sore hari jam 15.30-18.00 WIB.

- Pengamatan dilakukan dengan 6 kali pengulangan di hutan pinus dan 6 kali di hutan campuran, serta setiap titiknya memiliki waktu pengamatan yang sama setiap harinya.

c. Metode rapid asessment

Kondisi umum areal pengamatan diamati dengan metode rapid assessment merupakan modifikasi dari habitat assessment untuk mendapatkan gambaran secara umum tipe vegetasi ditemukannya keberadaan burung. Kegiatan ini bertujuan untuk mengetahui jenis tumbuhan penyusun habitat secara umum (Brower, J.E., Zar, J.H., 1990). Untuk meminimalisir bias dalam identifikasi jenis burung, maka digunakan pula metode pengenalan secara langsung oleh orang yang mengerti atau mengenal burung-burung yang ada di kawasan tersebut seperti masyarakat setempat, polisi hutan (polhut), ataupun seorang yang ahli mengenai burung.

2. Pengumpulan data sekunder

Pengumpulan data sekunder diperoleh dari berbagai sumber atau studi literatur, yaitu Panduan Pengamatan Burung-Burung di Sumatera, Jawa, Bali, dan Kalimantan dari perpustakaan Universitas Lampung, Data Hutan Mandailing Natal dari Kantor Dinas Kehutanan dan Perkebunan Kabupaten Mandailing Natal serta Statistik Daerah Kecamatan Muarasipongi 2012 dari Kantor Kecamatan Muarasipongi. Studi literatur mendukung penelitian, seperti karakteristik lokasi penelitian dan data pendukung lainnya yang sesuai dengan topik penelitian. 


\section{Analisis Data}

Analisis keanekaragaman jenis burung

Untuk mengetahui keanekaragaman jenis dihitung dengan menggunakan indeks keanekaragaman Shannon-Wienner (Odum, 1971), dengan rumus sebagai berikut:

Keterangan :

$$
H^{\prime}=-\sum P i \ln (P i) \text {, dimana } P i=(n i / N)
$$

$\mathrm{Pi}=$ Jumlah proporsi kelimpahan satwa spesies $\mathrm{i}$

$H^{\prime}=$ Indeks keanekaragaman Shannon-Wienner

$n i=$ Jumlah individu jenis ke-i

$N=$ Jumlah individu seluruh jenis

$\mathrm{Ln}=$ Logaritma natural

Kriteria nilai indeks keanekaragaman Shannon - Wiener $\left(H^{\prime}\right)$ adalah sebagai berikut:

$$
\begin{array}{ll}
H^{\prime}<1 & : \text { keanekaragaman rendah } \\
1<H^{\prime} \leq 3 & : \text { keanekaragaman sedang } \\
H^{\prime}>3 & : \text { keanekaragaman tinggi }
\end{array}
$$

\section{Indeks kesamarataan}

Indeks kesamarataan digunakan untuk mengetahui kesamarataan setiap spesies dalam setiap komunitas yang dijumpai. Indeks kesamarataan diperoleh dengan mengunakan rumus sebagai berikut:

Keterangan :

$$
J=H^{\prime} / H \max \text { atau } J=-\Sigma P i \ln (P i) / \ln (S)
$$

$$
J=\text { Indeks kesamarataan } S=\text { Jumlah jenis }
$$

Kriteria indeks kesamarataan $(J)$ (Daget, 1976) adalah sebagai berikut :

$$
\begin{array}{ll}
0<J \leq 0,5 & : \text { Komunitas tertekan } \\
0,5<J \leq 0,75 & : \text { Komunitas labil } \\
0,75<J \leq 1 & : \text { Komunitas stabil }
\end{array}
$$

\section{Analisis kesamaan spesies antar habitat}

Indeks kesamaan (Similarity index) diperlukan untuk mengetahui tingkat kesamaan komposisi spesies antar dua habitat, dihitung dengan menggunakan rumus (Odum, 1993).

$\mathrm{IS}=2 \mathrm{C} /(\mathrm{A}+\mathrm{B})$

Keterangan : $\quad \mathrm{C}=$ jumlah spesies yang sama pada kedua komunitas

$\mathrm{A}=$ jumlah spesies dalam komunitas $\mathrm{A}$

$\mathrm{B}=$ jumlah spesies dalam komunitas $\mathrm{B}$

\section{Analisis deskriptif}

Analisis deskriptif digunakan dalam penggunaan habitat dan vegetasi oleh burung, ditabulasikan dan diuraikan secara deskriptif berdasarkan hasil pengamatan yang dilakukan.

\section{HASIL DAN PEMBAHASAN}

\section{Hasil Penelitian}

\section{Keanekaragaman jenis burung}

Tiga puluh delapan jenis burung yang berasal dari 20 famili ditemukan di hutan pinus dan hutan campuran Muarasipongi pada bulan Agustus 2013 (Tabel 1). Di hutan pinus terdapat 19 jenis burung dan di hutan campuran terdapat 24 jenis, dengan 5 jenis burung yang ditemukan pada kedua tipe hutan. 
Tabel 1. Jenis-jenis burung yang ditemukan di hutan pinus dan hutan campuran Muarasipongi Kabupaten Mandailing Natal.

\begin{tabular}{|c|c|c|c|c|}
\hline \multirow[t]{2}{*}{ No } & \multirow[t]{2}{*}{ Nama Burung } & \multirow[t]{2}{*}{ Famili } & \multicolumn{2}{|c|}{ Jumlah Perjumpaan burung } \\
\hline & & & $\begin{array}{c}\text { Hutan } \\
\text { pinus }\end{array}$ & $\begin{array}{c}\text { Hutan } \\
\text { campuran }\end{array}$ \\
\hline 1. & Bondol jawa (LC) & Ploceidae & 7 & - \\
\hline 2. & Bondol haji (LC) & Ploceidae & 5 & - \\
\hline 3. & Bondol peking (LC) & Ploceidae & 8 & - \\
\hline 4. & Cucak kutilang (LC) & Pycnonotidae & 10 & 12 \\
\hline 5. & Elang hitam* (LC) & Accipitridae & 2 & 4 \\
\hline 6. & Madu kelapa* (LC) & Nectariniidae & - & 9 \\
\hline 7. & Madu sriganti* (LC) & Nectariniidae & - & 5 \\
\hline 8. & Sikatan bubik (LC) & Muscicapidae & - & 13 \\
\hline 9. & Cabai jawa (LC) & Dicaeidae & 10 & - \\
\hline 10. & Cabai merah (LC) & Dicaeidae & 6 & - \\
\hline 11. & Cabai polos (LC) & Dicaeidae & 25 & - \\
\hline 12. & Cabai tungir cokelat (NT) & Dicaeidae & 8 & - \\
\hline 13. & Gereja erasia (LC) & Ploceidae & 14 & - \\
\hline 14. & Perenjak jawa (LC) & Sylviidae & 10 & - \\
\hline 15. & Remetuk laut (LC) & Acanthizidae & - & 7 \\
\hline 16. & Cinenen kelabu (LC) & Sylviidae & - & 9 \\
\hline 17. & Takur tulung-tumpuk*(NT) & Capitonidae & - & 1 \\
\hline 18. & Takur tenggeret (LC) & Capitonidae & - & 1 \\
\hline 19. & Kicuit kerbau (LC) & Motacilidae & - & 11 \\
\hline 20. & Kacamata biasa (LC) & Zosteropidae & 19 & 15 \\
\hline 21. & Merbah crukcuk(LC) & Pycnonotidae & 3 & 5 \\
\hline 22. & Cicadaun sayap biru (LC) & Chloropseidae & 1 & 3 \\
\hline 23. & Merbah belukar (LC) & Pycnonotidae & - & 19 \\
\hline 24. & Pelanduk semak (LC) & Timaliidae & - & 14 \\
\hline 25. & Cinenen pisang (LC) & Sylviidae & - & 22 \\
\hline 26. & Cici merah (LC) & Sylviidae & - & 10 \\
\hline 27. & Layang-layang loreng (LC) & Hirundinidae & 4 & - \\
\hline 28. & Layang-layang rumah (LC) & Hirundinidae & 8 & - \\
\hline 29. & Kareo padi (LC) & Rallidae & - & 1 \\
\hline 30. & Perkutut (LC) & Columbidae & 3 & - \\
\hline 31. & Cipoh kacat (LC) & Aegithinidae & - & 1 \\
\hline 32. & Empuloh janggut (LC) & Pycnonotidae & - & 4 \\
\hline 33. & Pijantung besar*(LC) & Nectariniidae & - & 7 \\
\hline 34. & Kipasan belang (LC) & Rhipiduridae & - & 2 \\
\hline 35. & Gelatik batu kelabu (LC) & Paridae & - & 1 \\
\hline 36. & Munguk beledu (LC) & Sittidae & - & 8 \\
\hline 37. & Cucak kuricang (LC) & Pycnonotidae & 7 & - \\
\hline 38. & Cabai bunga api (LC) & Dicaeidae & 11 & - \\
\hline \multirow{2}{*}{\multicolumn{3}{|c|}{ Total Individu }} & 161 & 184 \\
\hline & & & \multicolumn{2}{|c|}{345} \\
\hline \multirow{2}{*}{\multicolumn{3}{|c|}{ Indeks keanekaragaman $\left(\mathrm{H}^{\prime}\right)$}} & 2.731 & 2.881 \\
\hline & & & \multicolumn{2}{|c|}{3.358} \\
\hline \multicolumn{3}{|c|}{ Indeks kesamarataan $(\mathrm{J})$} & 0.927 & 0.906 \\
\hline
\end{tabular}

Keterangan :

* : Dilindungi berdasarkan PP No 7 tahun 1999 tentang pengawetan jenis tumbuhan dan satwa

LC : Least Concern/ Risiko Rendah berdasarkan IUCN

NT : Near Threatened/Hampir terancam berdasarkan IUCN 
Jumlah burung yang ditemukan di hutan campuran $(\mathrm{N}=24)$ lebih banyak dibandingkan dengan hutan pinus $(\mathrm{N}=19)$ dan $(\mathrm{N}=5)$ jenis burung yang ditemukan dikedua hutan. Hal ini menunjukkan bahwa hutan campuran Muarasipongi menjadi habitat serta memberikan peranan yang baik bagi keberadaan burung, seperti jumlah vegetasi yang beranekaragam, adanya ketersediaan pakan, penebangan pohon serta penembakan burung cenderung sedikit. Berbeda dengan hutan pinus yang umumnya didominasi oleh tumbuhan bawah serta faktor lain seperti penebangan pohon, pengubahan lahan menjadi lahan pertanian menyebabkan jumlah burung semakin sedikit ditemukan. Vegetasi yang dijumpai di hutan campuran adalah jenis pulai, beringin, kayu manis, aren, bayur, durian, (Tabel 2).

Tabel 2. Jenis tumbuhan yang ditemukan di hutan campuran Muarasipongi.

\begin{tabular}{clll}
\hline No & Nama tumbuhan & \multicolumn{1}{c}{ Nama ilmiah } & \multicolumn{1}{c}{ Famili } \\
\hline 1. & Bayur & Pterospermum javanicum & Malvaceae \\
2. & Pulai & Alstonia scholaris & Apocynaceae \\
3. & Beringin & Ficus benjamina & Moraceae \\
4. & Petai & Parkia speciosa & Fabaceae \\
5. & Kayu Manis & Cinnamomum burmannii & Lauraceae \\
6. & Kedondong & Spondias dulcis & Anacardiaceae \\
7. & Aren & Arenga pinnata & Arecaceae \\
8. & Pinang & Areca catechu & Arecaceae \\
9. & Gamal & Gliricidia sepium & Fabaceae \\
10. & Bacang & Mangifera foetida & Anacardiaceae \\
11. & Ki Ciat & Ficus grossularioides & Moraceae \\
12. & Ara & Ficus racemosa & Moraceae \\
13. & Karet & Hevea brasiliensis & Euphorbiaceae \\
14. & Putri Malu & Mimosa pudica & Fabaceae \\
15. & Burahol & Stelechocarpus burahol & Annonaceae \\
16. & Durian & Durio zibethinus & Bombacaceae \\
17. & Bambu Betung & Dendrocalamus asper & Poaceae \\
18. & Rumput Palem & Setaria palmifolia & Poaceae \\
19. & Belimbing Tanah & Oxalis barrelieri & Oxalidaceae \\
20. & Sembung Rambat & Mikania micrantha & Asteraceae \\
21. & Senduduk & Melastoma malabathricum & Melastomataceae \\
22. & Bunga Malpen & Malvaviscus penduliflorus & Malvaceae \\
23. & Nilam & Pogostemon cablin & Lamiaceae \\
24. & Puspa & Schima wallichii & Theaceae \\
25. & Nangka & Artocarpus heterophyllus & Moraceae \\
26. & Tekalong & Artocarpus elasticus & Moraceae \\
\hline & & & \\
\hline
\end{tabular}

Vegetasi ditemukan di hutan pinus yang mendukung habitat serta keberadaan burung umumnya didominasi oleh tumbuh-tumbuhan bawah atau dikategorikan dalam semai serta pancang seperti glagah, putri malu, saliara, tapak dara (Tabel 3). Adanya perbedaan komposisi vegetasi atau jenis tumbuhan yang ditemukan di hutan pinus dan hutan campuran, menyebabkan adanya perbedaan jumlah jenis burung yang ditemukan di dua tipe hutan dengan indeks kesamaan jenis (IS) burung (Tabel 4) yang berbeda. 
Tabel 3. Jenis tumbuhan yang ditemukan di hutan pinus Muarasipongi.

\begin{tabular}{clll}
\hline No & Nama tumbuhan & \multicolumn{1}{c}{ Nama ilmiah } & \multicolumn{1}{c}{ Famili } \\
\hline 1. & Glagah & Saccharum spontaneum & Poaceae \\
2. & Kantong Semar & Nepenthes ampullaria & Nepenthaceae \\
3. & Benalu & Loranthus spp & Loranthaceae \\
4. & Lasiandra & Tibouchina semidecandra & Melastomataceae \\
5. & Putri Malu & Mimosa pudica & Fabaceae \\
6. & Saliara & Lantana camara & Verbenaceae \\
7. & Bandotan & Ageratum conyzoides & Asteraceae \\
8. & Tapak Dara & Catharanthus roseus & Apocynaceae \\
9. & Sembung Rambat & Mikania micrantha & Asteraceae \\
10. & Aren & Arenga pinnata & Arecaceae \\
11. & Gamal & Gliricidia sepium & Fabaceae \\
12. & Teki Ladang & Cyperus rotundus & Cyperaceae \\
13. & Tusam & Pinus merkusii & Pinaceae \\
14. & Pecut Kuda & Stachytarpheta jamaicensis & Verbenaceae \\
15. & Sidaguri & Sida rhombifolia & Malvaceae \\
16. & Bauhinia Rambat & Bauhinia semibifida & Fabaceae \\
17. & Rumput Grinting & Cynodon dactylon & Poaceae \\
18. & Kemiri & Aleurites moluccana & Euphorbiaceae \\
\hline
\end{tabular}

Tabel 4. Indeks kesamaan jenis burung pada tipe vegetasi di hutan pinus dan hutan campuran Muarasipongi.

\begin{tabular}{lc}
\hline \multicolumn{1}{c}{ Keterangan } & Jumlah \\
\hline Jumlah spesies dalam komunitas hutan pinus (A) & 19 \\
Jumlah spesies dalam komunitas hutan campran(B) & 24 \\
Jumlah spesies yang sama pada kedua komunitas (C) & 5 \\
\hline \multicolumn{1}{c}{ Indeks Kesamaan Jenis (IS) } & 0.277 \\
\hline
\end{tabular}

\section{Pembahasan}

\section{Indeks keanekaragaman jenis burung}

Berdasarkan hasil penelitian yang telah dilakukan di hutan pinus dan hutan campuran, diketahui bahwa total jenis burung yang ditemukan dikedua tipe habitat tersebut sebanyak 38 jenis, total individu sebanyak 345 ekor dan total famili sebanyak 20 famili. Lima jenis burung yang sama ditemukan dikedua lokasi yakni di hutan pinus dan hutan campuran. Total jenis burung yang ditemukan di hutan pinus sebanyak 19 jenis dengan jumlah total individu sebanyak 161 ekor dan total famili sebanyak 9 famili, sedangkan di hutan campuran sebanyak 24 jenis dengan total individu sebanyak 184 ekor yang berasal dari 16 famili.

Nilai indeks keanekaragaman jenis burung di hutan pinus sebesar 2.731 dan hutan campuran 2.881, yang berarti keanekaragaman jenis burung didua tipe hutan tinggi ( $\left.\mathrm{H}^{\prime}>3\right)$. Hal ini menunjukkan bahwa hutan pinus dan campuran di Muarasipongi menjadi habitat serta memberikan peranan yang baik bagi keberadaan burung untuk melakukan aktivitas membuat sarang, bermain, berlindung dari hewan pemangsa dan membesarkan anak.

\section{Indeks kesamarataan}

Nilai kesamarataan di hutan pinus dan campuran Muarasipongi yang bernilai 0,923, sesuai dengan kriteria indeks kesamarataan Daget (1976) yang menyatakan bahwa jika nilai indeks kesamarataan antara 0.75 sampai dengan 1 atau $0.75<\mathrm{J} \leq 1$, maka komunitas dimasukkan ke dalam kategori stabil. Penelitian didua lokasi yang berbeda yakni hutan pinus dan hutan campuran, ditemukan sebanyak 19 jenis burung di hutan pinus dengan total 
individu sebanyak 161 ekor dan total famili sebanyak 9 famili, sedangkan di hutan campuran sebanyak 24 jenis dengan total individu sebanyak 184 ekor yang berasal dari 16 famili (Gambar 2). Berdasarkan Nilai kesamarataan (J) di hutan pinus dan campuran Muarasipongi, menunjukkan bahwa populasi jenis burung yang ada di hutan pinus dan campuran Muarasipongi merata sehingga populasi jenis burung dengan mudah mendapatkan ancaman, gangguan serta mudah mengalami kerusakan habitat (Martin, 2012).

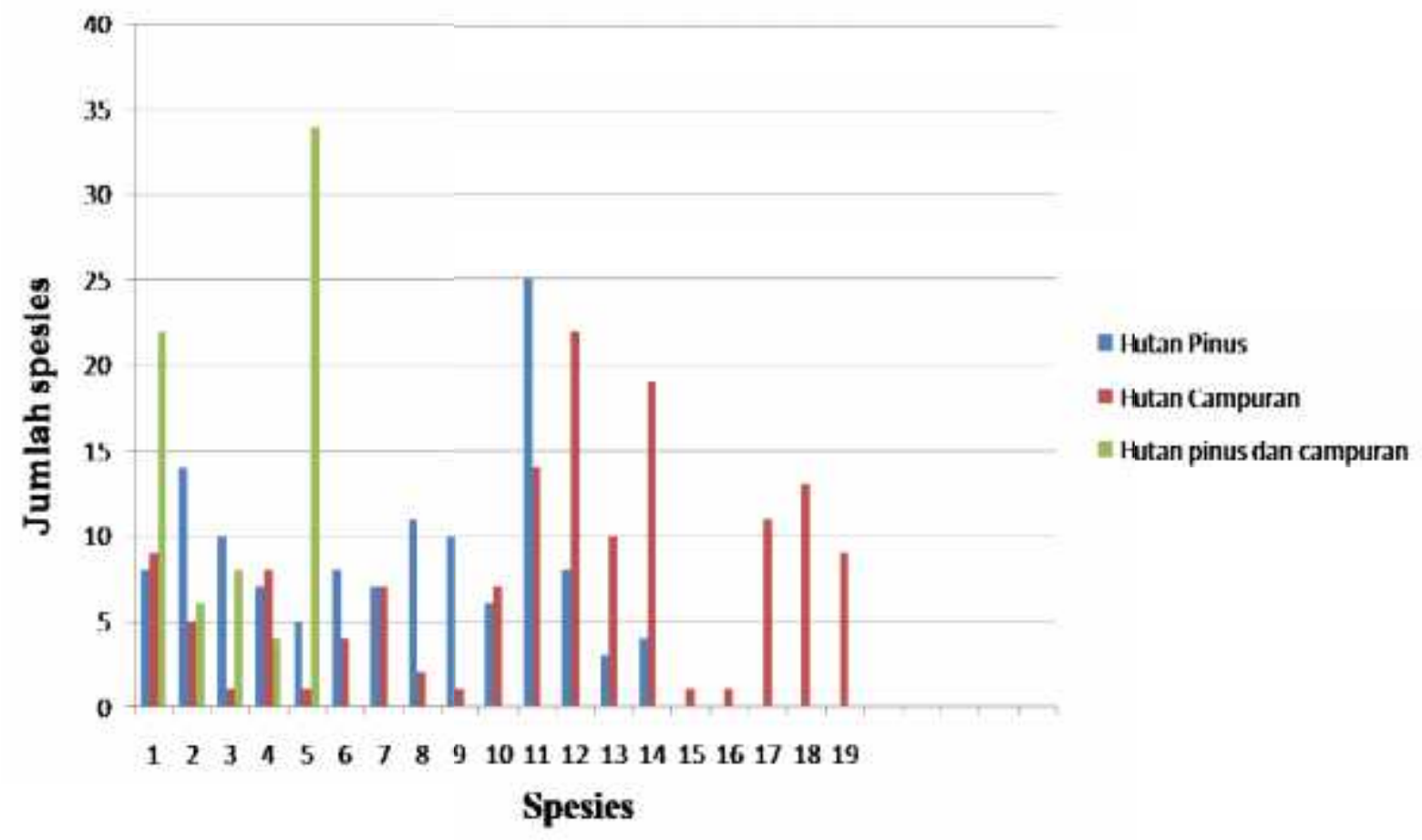

Gambar 2. Grafik jenis dan jumlah burung yang terdata saat pengamatan di hutan pinus dan hutan campuran Muarasipongi Agustus 2013.

Keterangan:

1. Layang-layang rumah, madu kelapa, cucak

11. Cabai polos,pelanduk semak kutilang

2. Gereja erasia,madu sriganti,elang hitam

3. Perenjak jawa,gelatik batu kelabu, merbah

12. Cabai tungir cokelat,cinenen pisang crukcuk

4. Bondol jawa,munguk beledu,cicadaun sayap biru

5. Bondol haji,cipoh kacat,kacamata biasa

6. Bondol peking,empuloh janggut

7. Cucak kuricang,pijantung besar

8. Cabai bunga api,kipasan belang

9. Cabai jawa, kareo padi

10. Cabai merah,remetuk laut

13. Perkutut, cici merah

14. Layang-layang loreng, merbah belukar

15. Takur tulung tumpuk

16. Takur tenggerek

17. Kicuit kerbau

18. Sikatan bubik

19. Cinenen kelabu

\section{Indeks kesamaan spesies antar habitat}

Indeks kesamaan (IS) atau Similarity index di kedua tipe habitat ini yakni hutan pinus dan hutan campuran adalah 0.277 yang berarti bahwa kesamaan spesies antar kedua habitat berbeda. Ada 5 jenis burung yang sama yang ditemukan di hutan pinus dan hutan campuran yaitu jenis cucak kutilang (Pycnonotus aurigaster), elang hitam (Ictinaetus malayensis), kacamata biasa (Zosterops palpebrosus), merbah crukcuk (Pycnonotus goiavier) dan cicadaun sayap biru (Chloropsis cochinchinensis). Indeks kesamaan ini akan memiliki nilai sama dengan 1 apabila terdapat kesamaan secara penuh atau jika serangkaian spesies dari kedua 
komunitas yang dibandingkan identik (Rohadi, 2011). Berdasarkan data pengamatan, jumlah ditemukannya jenis burung di hutan campuran lebih banyak daripada di hutan pinus.

\section{Penyebab berkurang jenis burung}

Belum ada data yang jelas mengenai apa penyebab berkurang atau menghilangnya jenis burung yang terdapat di hutan pinus dan hutan campuran Muarasipongi. Terutama dihutan pinus yang penanamannya dimulai pada tahun 1983 kondisinya cukup memprihatinkan, yakni mulai dari penanaman, pemeliharaan, perawatan, pemanenan, penjarangan serta penebangan belum memiliki tata kelola dan sistem manajemen yang baik. Sampai saat ini, banyak pohon pinus yang ditebang oleh orang-orang yang tidak bertanggung jawab serta pengerusakan kawasan hutan pinus untuk dijadikan sebagai lahan pertanian atau perkebunan.

\section{Status lindung}

Peraturan Pemerintah nomor 7 tahun 1999 tentang pengawetan jenis tumbuhan dan satwa liar, adalah elang hitam (Ictinateus malayensis) dari famili Accipitridae, madu kelapa (Anthreptes malacensis) dari famili Nectariniidae, madu sriganti (Nectarinia jugularis) famili Nectariniidae, takur tulung tumpuk (Megalaima javensis) dari famili Capitonidae, serta pijantung besar (Arachnothera robusta) dari famili Nectariniidae. Menurut International Union for Conservation of Nature (IUCN) menempatkan jenis burung takur tulung tumpuk (Megalaima javensis) dari famili Capitonidae pada Near Threatened (NT) atau hampir terancam. Empat jenis lainnya tergolong pada Least Concern/ Resiko Rendah.

\section{Potensi wisata hutan pinus}

Wisata hutan pinus di Muarasipongi memiliki daya tarik tersendiri serta banyak dikunjungi para remaja ketika libur lebaran tiba. Namun pengelolaan serta perhatian pemerintah terkait hutan pinus tak kunjung datang. Bahkan, kerusakan hutan pinus dari hari kehari kian tinggi. Penebangan pohon, pencurian kayu, alih fungsi lahan serta pengerusakan habitat bagi satwa liar kerap ditemukan di hutan pinus. Padahal, potensi wisata hutan pinus bisa memberikan pengaruh yang besar terhadap bagi kesejahteraan masyarakat asal pengelolaan serta perhatian serius baik pemerintah daerah, maupun masyarakat lokal.

\section{KESIMPULAN DAN SARAN}

\section{Kesimpulan}

Berdasarkan penelitian dapat disimpulkan:

1. Spesies burung yang ditemukan selama penelitian berjumlah 19 jenis burung di hutan pinus , 24 jenis terdapat di hutan campuran serta 5 jenis burung yang ditemukan kedua tipe hutan. Keseluruhan burung yang ditemukan di hutan pinus dan hutan campuran Muarasipongi berjumlah 38 jenis yang berasal dari 20 famili. Terdapat 5 jenis burung yang dilindungi yaitu elang hitam (Ictinateus malayensis), madu kelapa (Anthreptes malacensis), madu sriganti (Nectarinia jugularis), takur tulung tumpuk (Megalaima javensis), serta pijantung besar (Arachnothera robusta).

2. Keanekaragaman jenis burung di hutan pinus dan hutan campuran Muarasipongi 2.731 dan 2.881 yang berarti tinggi dan indeks kesamaratannya termasuk ke dalam kategori stabil dengan indeks kesamarataan sebesar 0.923.

3. Nilai indeks kesamarataan jenis burung di hutan pinus dan hutan campuran Muarasipongi sebesar 0.923, yang berarti kelimpahan individu spesies burung merata.

4. Nilai indeks kesamaan jenis (IS) burung di hutan pinus dan di hutan campuran Muarasipongi pada kedua tipe habitat sebesar 0.277 yang berarti yang berarti bahwa kesamaan spesies antar kedua habitat berbeda.

5. 


\section{Saran}

Dari hasil penelitian, disarankan:

1. Perlunya penelitian tentang pengaruh komposisi vegetasi terhadap keanekeragaman jenis burung di hutan pinus dan hutan campuran Muarasipongi.

2. Adanya pembinaan mengenai potensi sumberdaya alam terutama hutan pinus Muarasipongi yang semakin hari semakin rusak, mengingat hutan ini memiliki peranan yang cukup penting bagi masyarakat disekitar hutan serta fungsinya terhadap upaya penyelamatan dan perlindungan lingkungan.

3. Pentingnya pengawasan serta perhatian yang serius dari pihak-pihak terkait dengan upaya pelestarian burung di hutan pinus dan di hutan campuran Muarasipongi.

\section{DAFTAR PUSTAKA}

Bibby, C., Jones, M., dan Marsden, S. 2000. Survei burung. SMKG Mardi Yuana. Bogor. Diakses tanggal 15 Maret 2012 pukul $18.30 \mathrm{Wib}$

Brower, J.E, Zar , J.H. 1990. Feld and laboratory methods for general ecology. Wm.C. Brown, Dubuque, IA.

Daget. 1976. Les Modeles Mathematicques en Ecologie. Masson. Paris. Prancis

Dewi, B. S. 2011. Laporan praktikum ekologi lansekap di Anak Krakatau. Universitas Lampung, Bandar Lampung. Tidak dipublikasikan.

Harahap, Basyral H (2004): Pemerintah Kabupaten Madina Membangun Masyarakat yang Madani : Suatu Studi Perbandingan. Pemerintah Kabupaten Mandailing Natal. Panyabungan.

Mac Kinnon, J., Philipps, K., dan Van Balen, B. 2010. Seri Panduan Lapangan BurungBurung Di Sumatera, Jawa, Bali, dan Kalimantan. LIPI. Bogor.

Martin, D. 2012. Keanekaragaman jenis burung di Pulau Anak Krakatau Kawasan Cagar Alam Kepulauan Krakatau. Skripsi. Jurusan Kehutanan. Universitas Lampung. Bandar Lampung. Tidak dipublikasikan.

Odum, E.P. 1993. Dasar-dasar Ekologi. Buku. Gadjah Mada University Press. Yogyakarta.

Primack, R.B., J. Supriatna, M. Indrawan, dan P. Kramadibrata. 1998. Biologi Konservasi. $B u k u$. Yayasan Obor Indonesia. Jakarta

Rohadi, D. 2011. Keanekaragaman jenis burung di rawa universitas lampung. Skripsi. Jurusan Kehutanan. Universitas Lampung. Bandar Lampung. Tidak dipublikasikan.

Welty, J.C. 1982. The Life of Bird. Saunders College Publishing. Philadelphia. 